\title{
CAN Communication Based Modular Type Battery Management System for Electric Vehicles
}

\author{
Mustafa Turgut ${ }^{1}$, Raif Bayir ${ }^{2}$, Fecir Duran ${ }^{3}$ \\ ${ }^{I}$ Institute of Natural and Applied Sciences, Department of Mechatronics Engineering, \\ Karabuk University, \\ Karabuk, 78050, Turkey \\ ${ }^{2}$ Technology Faculty, Department of Mechatronics Engineering, Karabuk University, \\ Karabuk, 78050, Turkey \\ ${ }^{3}$ Technology Faculty, Department of Computer Engineering, Gazi University, \\ Ankara, 06560, Turkey \\ rbayir@karabuk.edu.tr
}

\begin{abstract}
Lithium ion batteries are widely used in portable electronic devices and electric vehicles. Although battery technology has been significantly improved, it does not fully meet the energy requirements of electric vehicles. Electric vehicle batteries are built by serial and parallel connections of many cells to provide sufficient power. Differences between cells during battery usage can shorten the battery life and even worse can cause fire and explosion. Therefore, there is a need for a battery management system to ensure that the voltage, temperature and current information of the battery cells are used as optimum conditions. Cell balancing should be used to ensure that the battery cells are charging simultaneously. Cell voltage and temperature are measured by connecting auxiliary slave board to each series battery pack. This information is controlled by a master board. In this application, the excess energy is converted to heat by the load resistor on the utility boards. Fuzzy logic control is used to control the load resistor with the switching element. The charge status of the battery was estimated using the main battery current and the mains voltage with the master board. This application has been tested on an electric vehicle. A low cost modular battery management system has been developed that can control the safe charging and discharging of the vehicle battery.
\end{abstract}

Index Terms-Battery management system; Fuzzy logic control; State of charge; Electric vehicles.

\section{INTRODUCTION}

The increase in environmental pollution and the reduction of energy sources cause the spread of electric vehicles instead of internal combustion engines [1]. Lithium ion batteries with high energy density are preferred in electric vehicles [2]. The goal of many studies with lithium ion batteries is to improve cycle life, reliability and other performance characteristics. With the development of the batteries, the automotive sector is accelerating their work on electric vehicles [3]. The battery pack contains hundreds of

Manuscript received 3 November, 2017; accepted 16 January, 2018.

This study was supported by Karabuk University within the scope of Scientific Research Projects with KBU-BAP-17-YL-040 code. cells connected in series and parallel to meet the high capacity requirements and the desired voltage for electric vehicle applications [4].

The BMS (Battery management system) is basically a request to control current and voltage during charging and discharging operations. Differences arise in the battery cells due to the reasons for production or working environment Several cell balancing topologies have been investigated to efficiently utilize the remaining capacities of the battery cells and prolong their useful life [5]-[8].

Determining SOC (State of Charge) for BMS is one of the most difficult tasks. It is difficult to determine the exact state of the SOC and there is no way of direct measurement Various methods are used to determine the SOC [9]-[14]. The SOC of the battery is determined and provides information about the available capacity of the battery. The most accurate results for the SOC estimation can be obtained by OCV (Open Circuit Voltage) measurement after the load is removed. The use of batteries at the time of charge-discharge does not give correct results. The current counting method calculates the remaining capacity according to the energy transferred into and out of the battery.

In this study, power and temperature information of the power is measured by slave boards and sent to the master board via CAN (Controller Area Network) network. Battery information is recorded on the SDMC (Secure Digital Memory Card) module with the master board instantly. The number of boards can be increased as the system allows the CAN network to communicate. Passive cell balancing technique is used. FLC (Fuzzy Logic Controller) is used in cell voltage balancing. The current counting method is used to estimate the SOC of the battery. If battery information is requested, it can be transferred to the computer via wireless communication module. The system has been tested on the charging, discharging and EA. The tests on the vehicle were carried out at the TUBITAK Efficiency Challenge Electric Vehicle competitions. 


\section{RECHARGEABLE BATTERY}

Rechargeable batteries; lead acid battery, Ni-Cd (Nickel Cadmium) battery, Ni-MH (Nickel Metal Hydride) battery, LiPO (Lithium Ion Polymer) battery and Li-Ion (Lithium Ion) battery. These batteries have high energy density.

Lead-acid batteries are the oldest and most mature technology in the storage of electricity. Lead-acid batteries are used at a very high density in solving storage problems in many areas due to their low investment cost, low selfdischarge among all rechargeable batteries, and relatively easy maintenance advantages [15].

Ni-Cd batteries have become a useful alternative in everyday applications due to their high energy densities, long cycle life and low maintenance requirements compared to lead-acid batteries [15], [16]. Memory effect is the greatest inadequacy. Ni-Cd batteries contain harmful chemical substances inside.

Ni-MH batteries have very high energy capacities. Nickel metal hydride batteries have an environmentally friendly structure compared to lead-acid and nickel-cadmium batteries because they do not contain harmful substances such as cadmium, lead or mercury. Ni-MH batteries have problems of self-discharge, nickel metal hydride batteries are insufficient for long-term energy storage. However, Liion is cheaper than batteries in terms of cost [16].

Li-Ion batteries have a wide working temperature range because they can be used between $-20{ }^{\circ} \mathrm{C}$ and $+60{ }^{\circ} \mathrm{C}$ for charging and $-40{ }^{\circ} \mathrm{C}$ to $+65^{\circ} \mathrm{C}$ for discharging. Capacities available at different $\mathrm{C}$ ratios and temperatures vary. The $\mathrm{Li}$ Ion battery cell voltages are $2.5 \mathrm{~V}$ to $4.2 \mathrm{~V}$ and approximately three times that of other battery types [17].

Lithium is a substance that can react very quickly, so there is a risk of bursting and burning during its use. Li-Ion batteries are arise dangerous situations when exposed to direct sunlight or high temperatures. During charging, the maximum value of the charging voltage must be maintained at constant current until it reaches $80 \%$ of the battery voltage. Then charging at constant voltage should be continued. Charging should be terminated when the charging current decreases by a certain level. Battery pack when Li-Ion battery cells are built in series and parallel connection, protection circuits are required to protect the battery cells from overcharging and excessive discharge. A graph of specific energy and power comparisons of rechargeable batteries is given in Fig. 1.

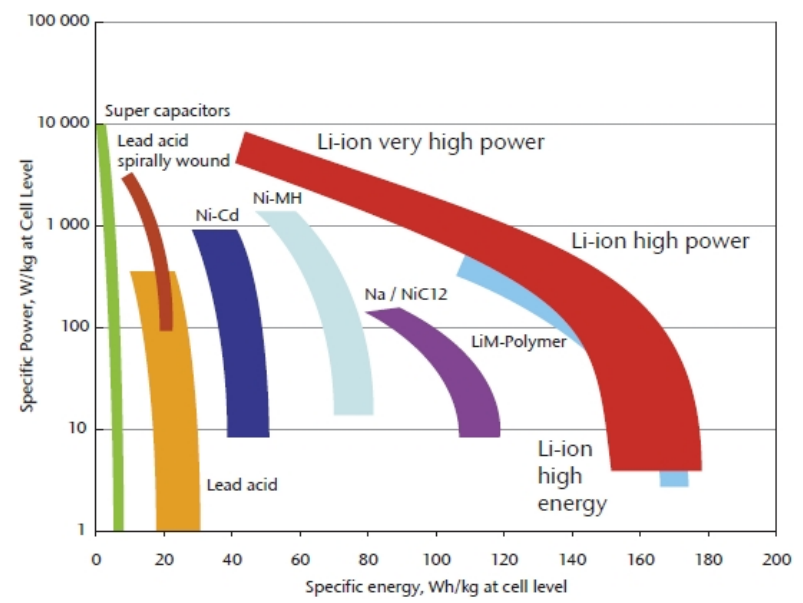

Fig. 1. Comparison of power and energy density of rechargeable batteries.

\section{BATTERY MANAGEMENT SYSTEM}

A system is a battery or battery pack that is made up of multiple cells. As the battery pack increases in series, the battery voltage increases. As parallel connections increase, battery current and battery capacity increase. BMS is a system that controls the charging and discharging of battery or battery packs. By acting as a protector in battery systems, it examines the current working states of the batteries and ensures that they remain within the optimum operating range. BMS functions provide data monitoring, calculation, protection and optimization.

The voltage, current and temperature of the battery cells are measured. The BMS calculates and compares with the measured battery data. The maximum and minimum cell voltages and temperatures of the battery are determined. The SOC status is calculated from the charge and discharge of the battery. The total voltage of the battery and the energy consumed $(\mathrm{kWh})$ are determined.

BMS measures the battery data and provides protection of the battery by interfering with the system when optimal values are exceeded. It protects battery cells from overcharging, overdischarge, high temperature, low temperature and short circuit.

BMS provides battery cell voltages optimization to maximize battery capacity and protect cells from excessive discharge during charging. With cell balancing, the excess energy in the battery cell transfers to the other cells by active cell balancing, or the excess converts energy into heat by passive cell balancing. In the case of overvoltage and undervoltage in one cell and when voltage stabilization is insufficient, it separates the battery from the system. This protects the battery against damage that may occur. BMS is designed to extend battery life and increase efficiency [18].

Voltage and temperature measurements are made on the slave board in the master-slave board battery management system. The measurement accuracy is higher than other BMS types [19]. The measured values are sent to the master board and BMS operations are performed. It is easy to change if any of the slave boards fail. Figure 2 shows the general structure of BMS.

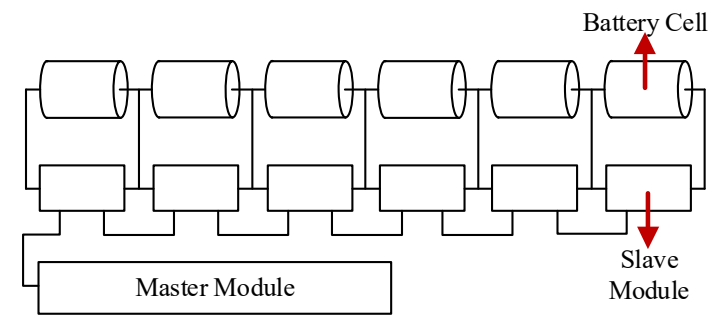

Fig. 2. BMS general structure.

Cells that are connected in parallel in batteries force each other to equalize their tensions. Thus, parallel connected cells automatically compensate for each other. In connected cells, the main arm current passes through the whole battery and the cell with the lowest capacity is identified. The battery cells have different capacities due to their nonequivalent charge and discharge.

In an unbalanced battery pack, one or more of the cells connected in series during charging will reach the maximum charge level before the others. If the battery is not charged, fully uncharged cells will be consumed before other cells on 
the shelf [20]. The passive cell balancing method used in Fig. 3 is shown.

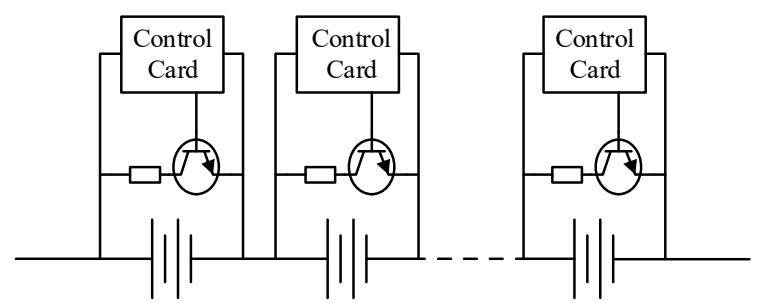

Fig. 3. Passive cell balancing method.

In theory, whereas active cell balancing methods are far superior to passive equalization methods, passive equalization methods are more efficient in practical applications. Active cell balancing methods have a lot of electronic circuit elements.

This leads to more complex designs and more money. Passive cell balancing methods only work when balancing is required and energy loss occurs both in the circuit and in the load resistance. In the active cell balancing method, the circuit is in standby mode and standby energy is consumed by the circuit. The total standby energy in the active cell balancing method may be more than the passive cell balancing method. In the active cell balancing method, energy is transferred from the cell to the battery pack or from the battery pack to the cell. The conversion process also works with a certain efficiency. Unless special components and designs are used, this yield is usually around $70 \%$ to $80 \%$. In this case, energy loss increases.

\section{MATERIAL AND METHOD}

\section{A. Electric Vehicle and Battery Pack}

Battery management system was developed for TÜBİTAK Electric Vehicle Races. Technical specifications of the electric vehicle are given in Table I.

TABLE I. TECHNICAL SPECIFICATIONS OF THE ELECTRIC VEHICLE.

\begin{tabular}{|c|c|c|}
\hline No & Property & Specifications \\
\hline 1 & Motor & $\begin{array}{l}\text { Two permanent magnet Brushless DC } \\
\text { motor }\end{array}$ \\
\hline 2 & Motor Drive & $\begin{array}{l}\text { Siemens S7 1200(Siemens, Munich, } \\
\text { Germany) programmable logic controller }\end{array}$ \\
\hline 3 & Chassis & Aluminum Chassis \\
\hline 4 & Shell & Carbon fiber shell \\
\hline 5 & Weight & $237 \mathrm{~kg}$ \\
\hline 6 & Driving range & $100 \mathrm{~km}$ \\
\hline 7 & Maximum speed & $97 \mathrm{~km} / \mathrm{h}$ \\
\hline 8 & Charger unit & $220 \mathrm{~V}$ AC input and built-in the car \\
\hline 9 & Other & $\begin{array}{l}\text { Electronic differential, a telemetry system, } \\
\text { the dynamic headlight system }\end{array}$ \\
\hline
\end{tabular}

A single-cell Li-Ion battery has low voltage, low capacity and energy storage and may not meet the energy requirements of an electric car; for this reason, many battery cells are connected in series and parallel to form a battery pack [11]. The battery pack used in this study was formed by connecting 28 serial NCR18650PF Li-ion battery cells from 8 connected groups connected in parallel. A slave board is attached to each group A system that works with the motherboard that controls these slave boards is designed. In this way, a battery management system which is high in efficiency and easy to install in battery pack has been established.

The specifications of the single battery cell and the battery pack are given in Table II.

TABLE II. TECHNICAL SPECIFICATIONS OF THE SINGLE CELL

\begin{tabular}{|c|c|c|}
\multicolumn{2}{c|}{ AND BATTERY PACK. } \\
\hline Specifications & Single Cell & Battery Pack \\
\hline Rated capacity & $2.6 \mathrm{Ah}$ & $20.8 \mathrm{Ah}$ \\
\hline Nominal voltage & $3.6 \mathrm{~V}$ & 100.8 \\
\hline Charging voltage & $4.2 \mathrm{~V}$ & $117.6 \mathrm{~V}$ \\
\hline Cut-off voltage & $2.5 \mathrm{~V}$ & $70 \mathrm{~V}$ \\
\hline Charging current & $1.375 \mathrm{~A}$ & $11 \mathrm{~A}$ \\
\hline C rate & $2 \mathrm{C}$ & $2 \mathrm{C}$ \\
\hline
\end{tabular}

\section{A. Experimental Setup}

It is composed of slave and master boards in BMS design. On the master board are current sensor, voltage sensor, LCD, role control circuit and remote communication module. The BMS block diagram in Fig. 4 is given below.

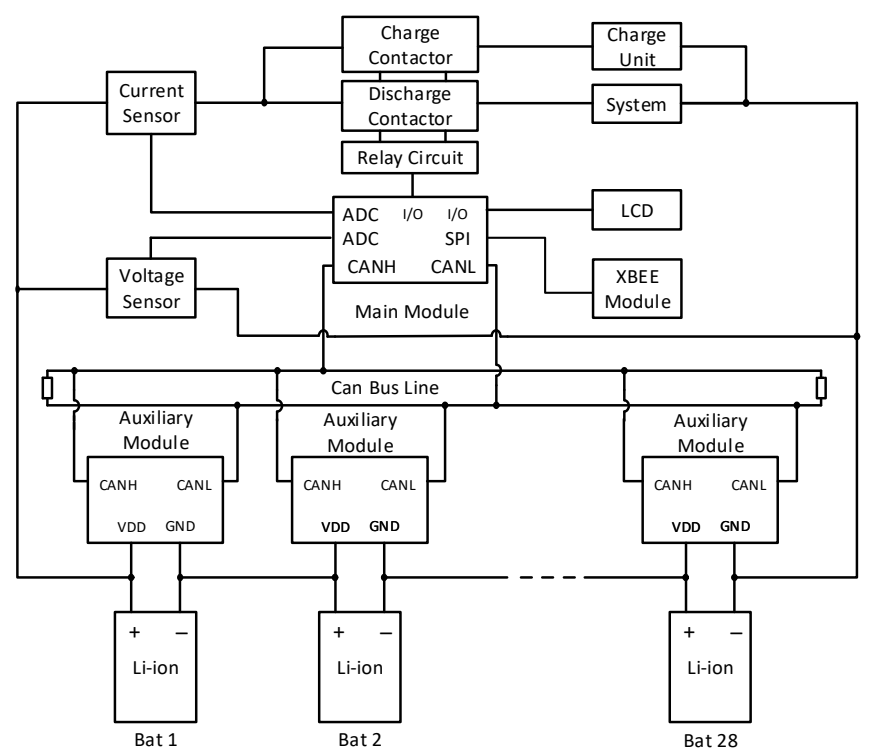

Fig. 4. BMS block diagram.

The slave board design is designed to be easily mountable on battery cells. Slave boards were made copper bar to be mounted on the cell. By means of these copper bar the slave boards remain stationary on the cell. The slave boards read the voltage and temperature information of the cells to which they are connected and send them to the motherboard via CAN network. It also balances according to the information received from the master board. The slave boards consist of six units: $5 \mathrm{~V}$ buck/boost converter, temperature sensor, voltage filtering, balancing circuit, CAN communication, warning. Figure 5 shows the slave board circuit. The PIC18F25K80 microprocessor, which is produced by Microchip company, is used as the BMS slave board processor. Extremely low power sleep mode makes it suitable for building control, elevator control, battery applications. It is widely used because it has 28 pin and 8 bit high performance processor. The NCP1402 integration of the Semiconductor company is used as a constant output converter. It provides a constant $5 \mathrm{~V}$ output between $0.8 \mathrm{~V}$ and $5.5 \mathrm{~V}$. The LM35 series temperature sensors deliver a voltage proportional to the temperature as output. When using the LM35, we do not need to set up a circuit for 
calibration. It draws a low current like $60 \mu \mathrm{A}$. It can measure between $-55^{\circ} \mathrm{C}$ and $150{ }^{\circ} \mathrm{C}$.
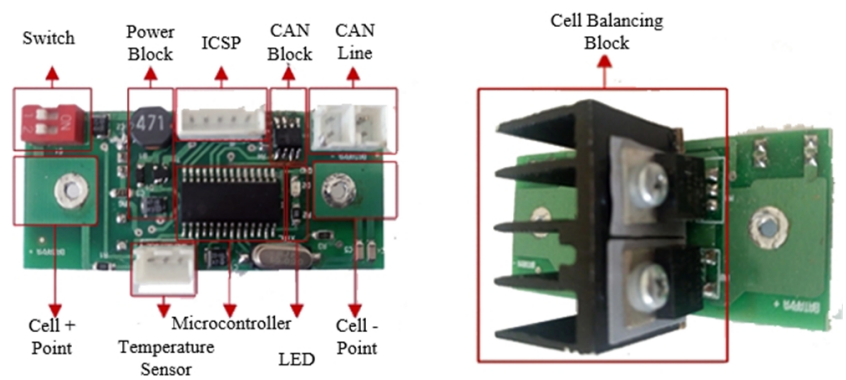

Fig. 5. Slave board circuit

The master board evaluates the voltage and temperature information sent via the CAN protocol from the slave boards and carries out the battery management system operations. The master board circuit consists of regulator, current, voltage, CAN communication, Wireless Communication and SDMC module circuits. The master board decides whether to stop or start charging and discharging. Calculates and displays the battery capacity. When necessary, the battery is being charged or disconnected from the charger. This prevents the batteries from over charging or over discharging.

As the BMS motherboard processor, LPC1768 microprocessor development card, which is produced by NXP company, is used. Figure 6 shows the master board circuit. LV-25P voltage sensor is used for voltage measurement. The voltage sensor is fed with $\pm 12 \mathrm{~V}$ symmetrical source. The working temperature is between $0{ }^{\circ} \mathrm{C}-70{ }^{\circ} \mathrm{C}$. The measurement range is $0 \mathrm{~V}-500 \mathrm{~V}$. ACS758LCB-100B-PPF-T current sensor is used for current measurement. The current sensor measures within $\pm 100 \mathrm{~A}$. The XBee Pro module is used for remote monitoring of the system. The microcontroller allows you to establish a seamless connection with virtually any computer with a serial port. It supports point-to-point or multi-point communication modes. The data rate is a maximum of $250 \mathrm{kbps}$ and a range of $1.6 \mathrm{~km}$. Figure 6 shows the master board circuit.

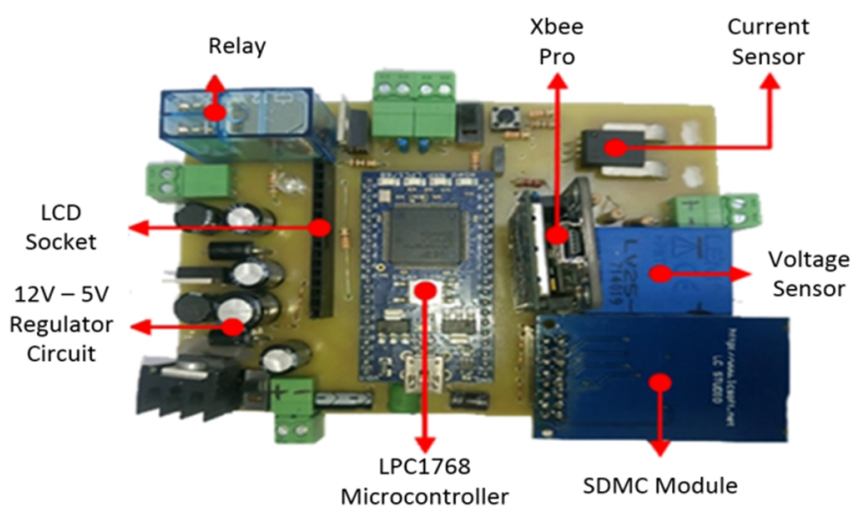

Fig. 6. Master board circuits.

The battery cells use battery management system circuits and a protection box in which the elements are located. Figure 7 shows the placement of the BMS circuits in the box.

The current counting method is used to estimate the SOC of the battery. Current measurement determines the accuracy of this method. This method is widely used because it is easy to apply

$$
S O C=S O C_{t 0}-\frac{1}{C_{N}} \int_{t 0}^{t} I \times d t .
$$

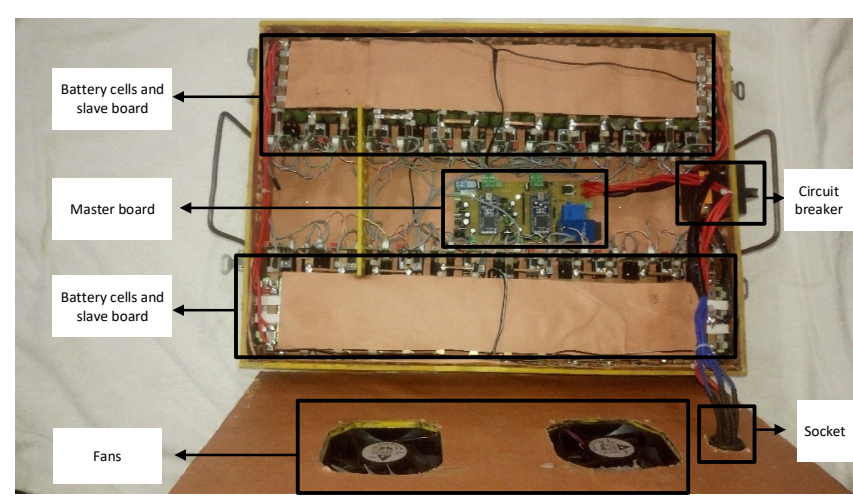

Fig. 7. BMS circuit box placement.

In (1), $S O C_{t 0}$ indicates the $S O C$ at the start time. The $C_{N}$ nominal capacity represents the coulombic efficiency during y discharge. When $S O C$ is calculated, it is calculated as $\mathrm{y}$ positive at charging and negative at discharge. What is important in the current counting method is to determine the $S O C$ state at $t 0$. This operation is continued until the battery is completely discharged by drawing a constant $1 \mathrm{~A}$ current from the fully charged battery. During this time, the battery voltage is instantaneously recorded. This battery voltage was initially assumed to be $0 \% S O C$ at the end of the discharge operation when it was $100 \%$ SOC and was scaled according to the stored data. This equation was created by Matlab program. In the curve equation, $S O C$ data is obtained according to the battery voltage (Fig. 8). In the case of charging the battery, SOC information is calculated by this calculation. If the battery is discharged, the current counting method is used. It is very important that the SOC information at the start of the current counting method is found correctly. With the operation of the electric vehicle, the $S O C$ information is obtained from the battery, which is obtained from the curve obtained by the curve equation. As the current starts to flow from the battery, the SOC estimation is continued by the current counting method.

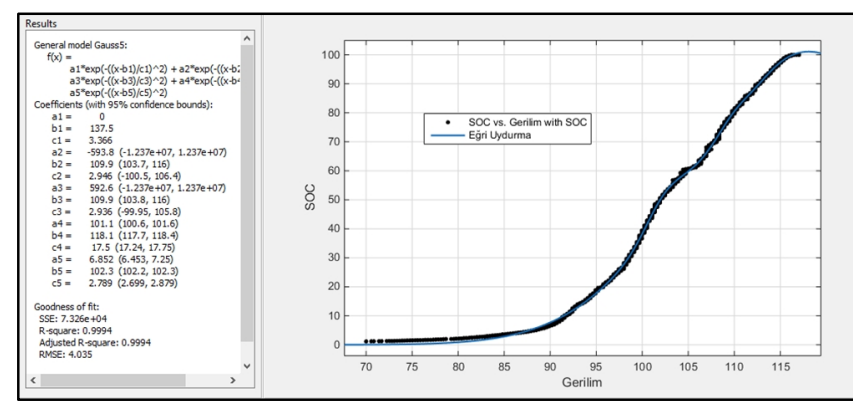

Fig. 8. Curve fitting with Matlab curve fitting.

The switching element in the cell balancing process is controlled by PWM (Pulse Width Modulation) equipment. The fill rate of PWM equipment is determined by FLC. FLC input variables are voltage error and voltage error change. The output variable is the PWM fullness ratio. In Fig. 9, FLC input and output membership functions are given. 

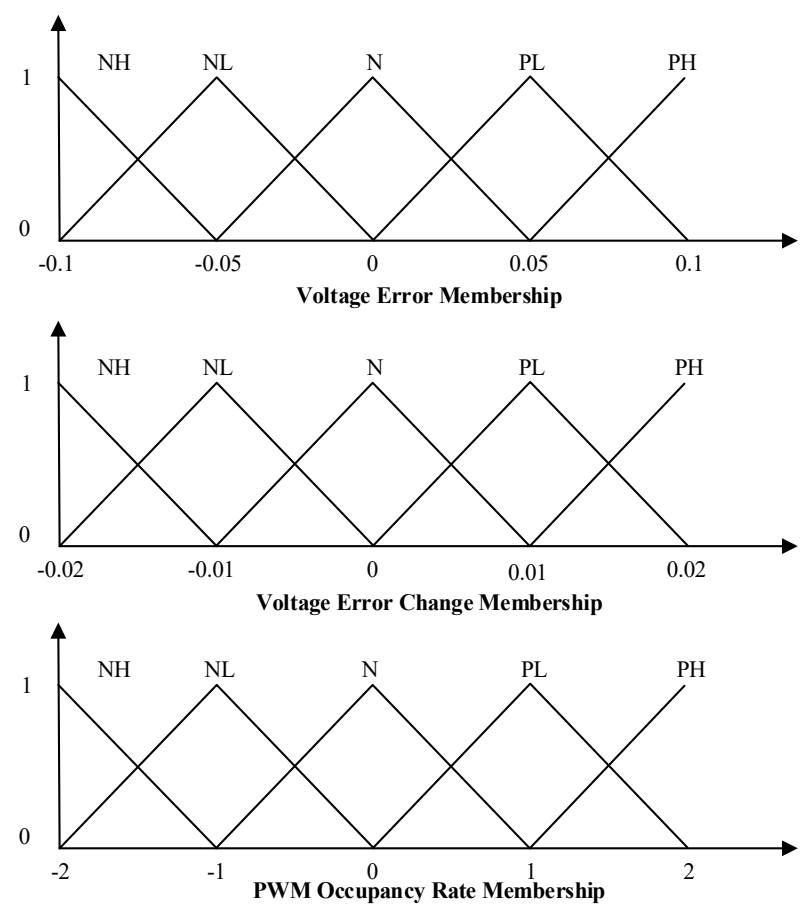

Fig. 9. Membership function.

\section{EXPERIMENTS}

Experimental studies are carried out in case of discharge, discharge and data obtained on electric vehicle.

\section{A. BMS Charging Test}

Charging of the batteries lasted 330 minutes. Before charging the battery, the maximum cell voltage was $2.94 \mathrm{~V}$ and the minimum cell voltage was $2.72 \mathrm{~V}$ between 28 cells. Since the beginning of the charging process, the capacity differences between the cells have been compensated by $0.04 \mathrm{~V}$. The system has been prevented from charging more cells reaching the upper limit voltage of the charger. From the minute all cells are full. The maximum and minimum cell voltage time graphs are given in Fig. 10.

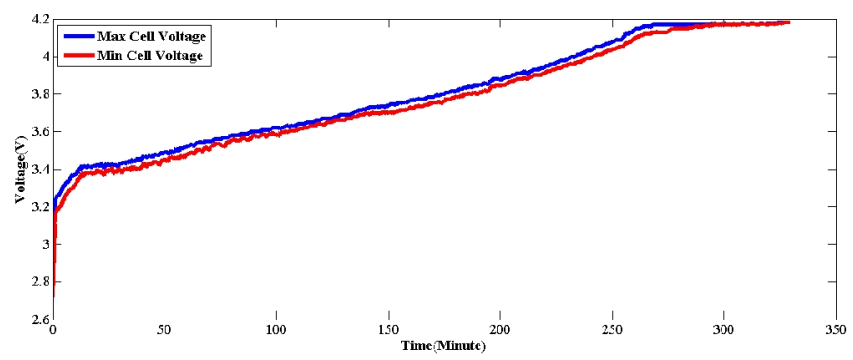

Fig. 10. Max-min cell voltage-time graph.

The temperature of the battery cells is observed to increase over time when the cell stabilization is active. At the time of balancing, the fan system did not work because the cell temperatures did not exceed $40{ }^{\circ} \mathrm{C}$. At the beginning of the charging process, cell temperatures are higher because of the high cell-to-cell capacity differences. Cell temperatures have returned to their initial values at the end of charging. The maximum and minimum cell temperatures are given in Fig. 10.

The voltages of Li-Ion batteries show a rapid increase up to nominal voltages, depending on their characteristics. Cell voltages increase linearly after nominal voltage. The total battery voltage time graph is given in Fig. 12.

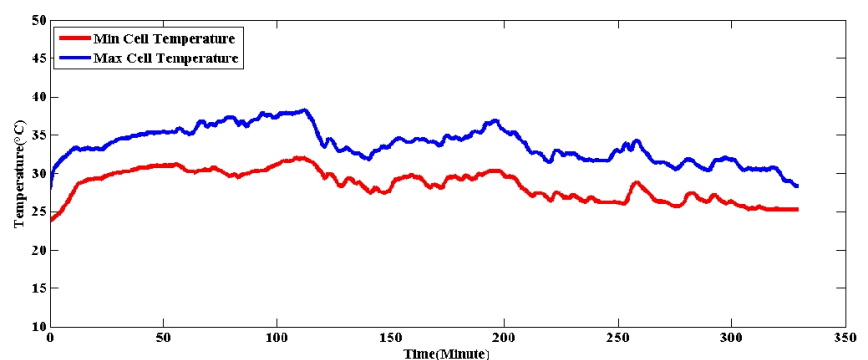

Fig. 11. Max-min cell temperature-time graph.

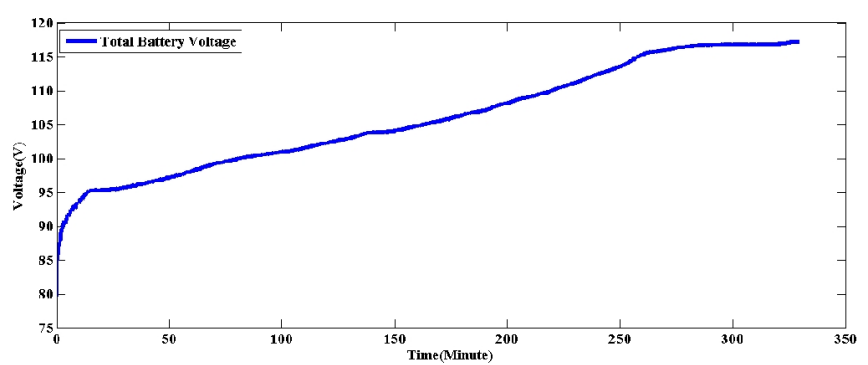

Fig. 12. Total battery voltage time graph.

The battery is initially charged at constant current. When the battery voltage reaches the upper limit of charging, the charging process is continued at constant voltage. At this point, the battery is charged precisely. Charging is terminated when main arm current decreases by $100 \mathrm{~mA}$. The total battery current time graph is given in Fig. 13 .

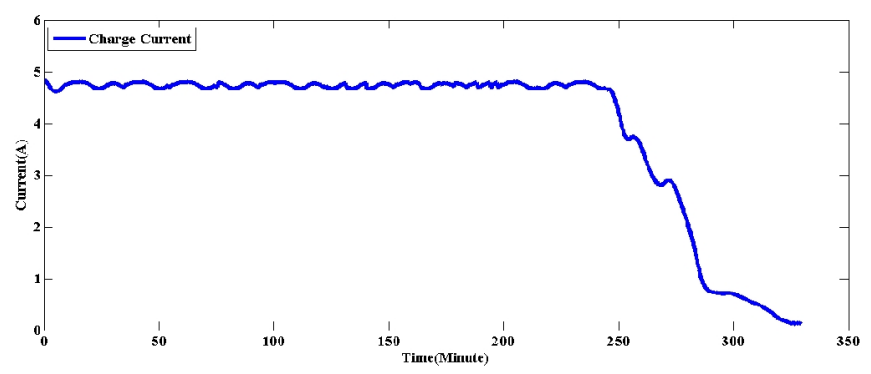

Fig. 13. Total battery current time graph.

It is estimated that the battery has $6 \%$ SOC status at the start. At the end of charging, it has $98 \%$ SOC status. It is understood that SOC estimation is done correctly on this page. The battery SOC time graph is given in Fig. 14.

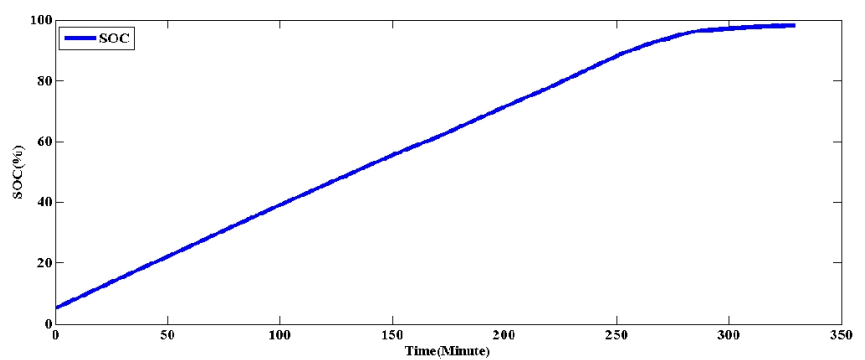

Fig. 14. Battery SOC time graph.

\section{B. BMS Discharging Test}

The cell balancing test was carried out under constant $1 \mathrm{~A}$ discharge current with Array 3711A DC load. This experiment was completed in 55 minutes. The $0.2 \mathrm{~V}$ voltage difference between the cells at the start was removed in the middle. The time chart of maximum and minimum cell voltages graph is given in Fig. 15.

It is observed that the cell temperature increases during the balancing process. The cell temperature starts to 
decrease when the capacity difference between cells decreases. The time chart of maximum and minimum cell temperatures graph is given in Fig. 16.

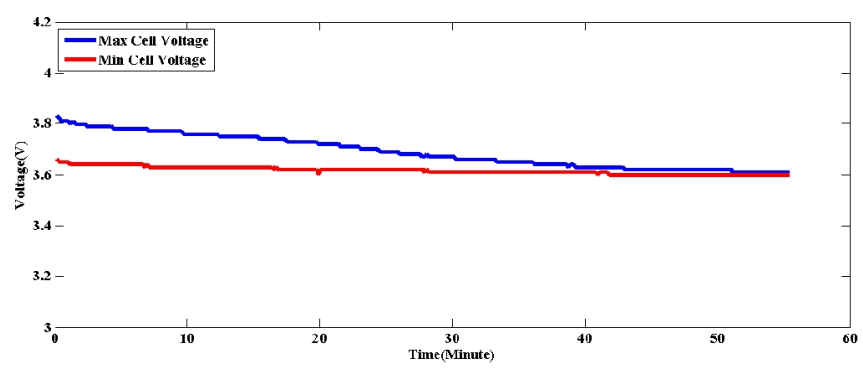

Fig. 15. Max-min cell voltage graph.

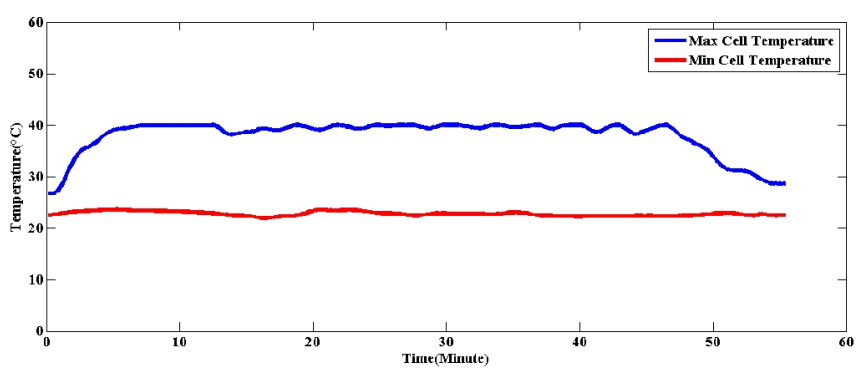

Fig. 16. Max-min cell temperature graph.

When the total battery voltage graph is examined, there is a rapid decrease in voltage in the first 30 minutes. This decrease in voltage means that cell stabilization is carried out by more than one cell. The total battery voltage time graph is given in Fig. 17.

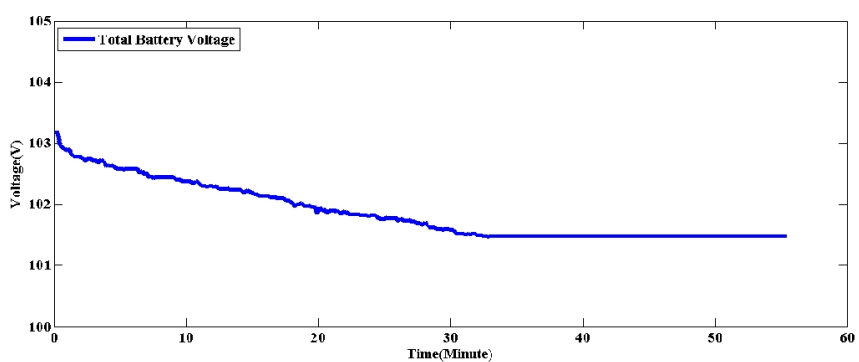

Fig. 17. Total battery voltage graph.

Discharged at constant 1 A with battery-powered load source. It is understood that the current measured by the system is $10 \mathrm{~mA}$ error. This error indicates how precise the current measurement of the system. The total battery current time graph is given in Fig. 18.

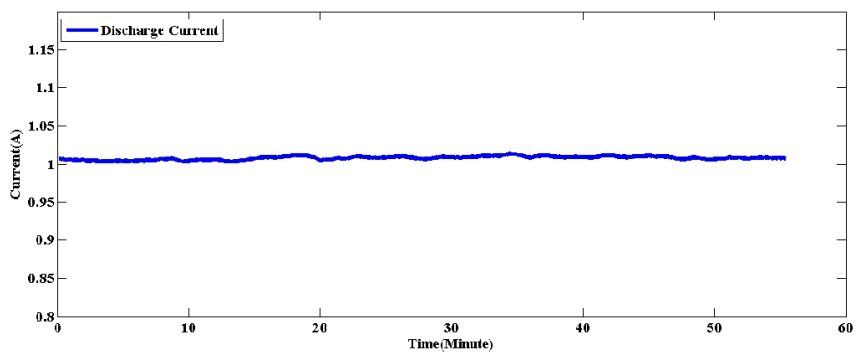

Fig. 18. Total current graph.

The battery pack is rapidly decreasing in the first 30 minutes of SOC state at discharge. Cell balancing was initially performed by many cells. The battery SOC time graph is given in Fig. 19.

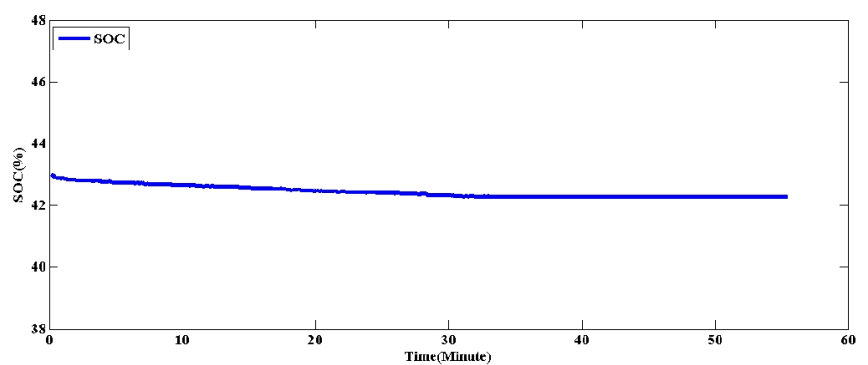

Fig. 19. Battery SOC time graph.

\section{BMS Vehicle Testing}

The system is tested on the electric car at the TUBITAK Efficiency Challenge Electric Vehicle in 2017 in Kocaeli/Turkey [21]. A photo of the electric vehicle is given in Fig. 20. During the race the battery information and vehicle speed were recorded instantaneously. These data are shown graphically.

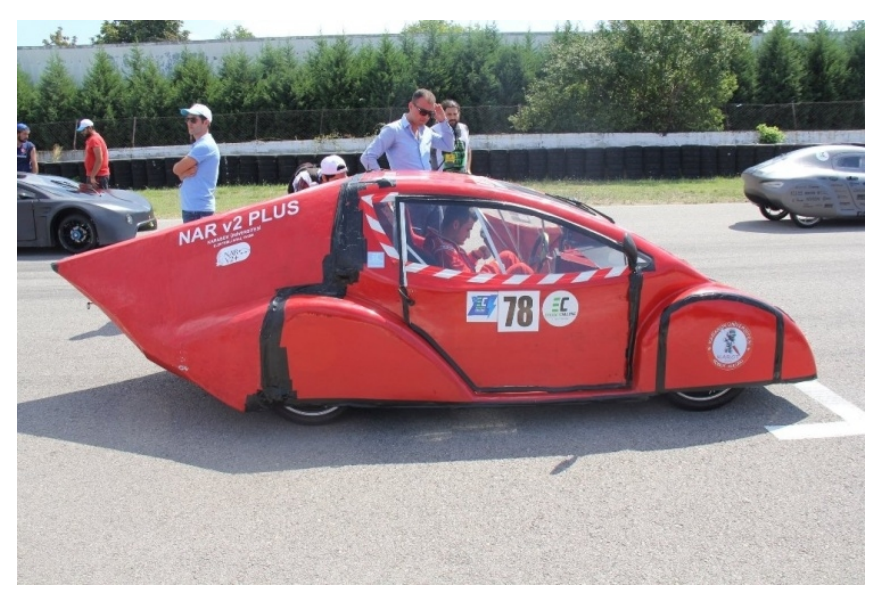

Fig. 20. Driving test of the electric vehicle.

The electric vehicle draws 12 A current from the average battery in the first 25 minutes. The car has been in the maintenance area for 27 minutes-30 minutes during the competition due to a technical breakdown. After 30 minutes, the electric vehicle completed the competition by drawing an average of $18 \mathrm{~A}$ current from the battery. The total battery current time graph is given in Fig. 21.

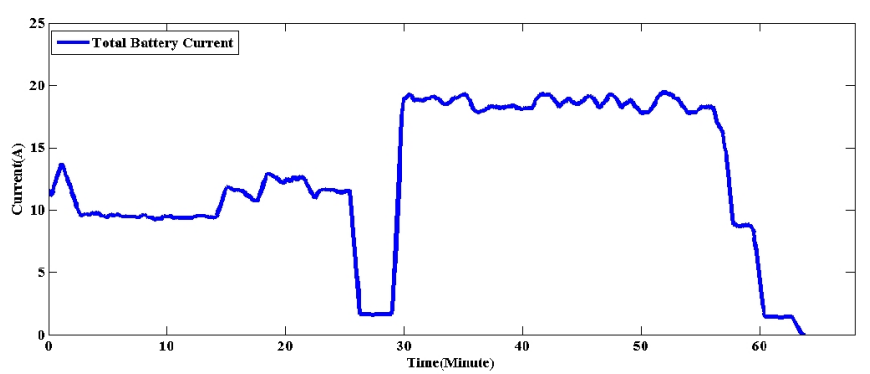

Fig. 21. Total battery current graph.

The car moved at an average speed of $32 \mathrm{~km} / \mathrm{h}$ in the first 27 minutes. Since the vehicle spent a lot of time coming to the maintenance area due to technical breakdown, it completed the race with an average speed of $39 \mathrm{~km} / \mathrm{h}$. Electric vehicle speed time graph is given in Fig. 22.

When voltage graphs are examined, sudden acceleration occurs when the battery voltage drops rapidly. When the battery voltage drops below the nominal voltages of the 
cells, the voltages are rapidly decreasing. At the end of the competition, the cell voltages are on average $2.8 \mathrm{~V}$. The time graph of maximum and minimum cell voltages is given in Fig. 23.

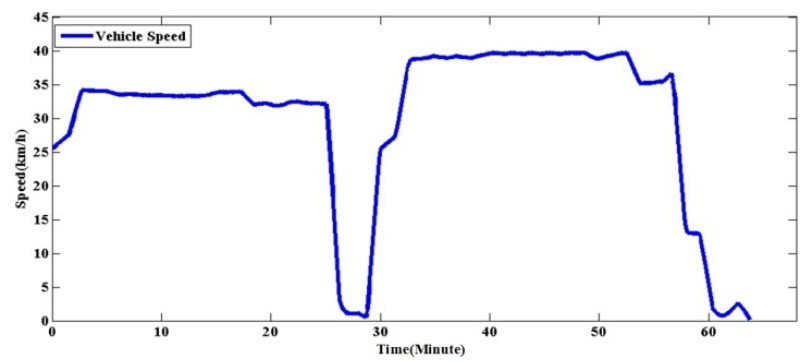

Fig. 22. Vehicle speed graph.

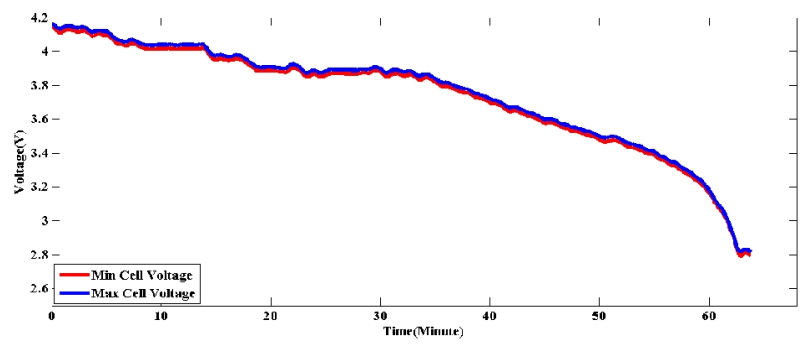

Fig. 23. Max-min cell voltage.

The total battery voltage time graph is given in Fig. 24 .

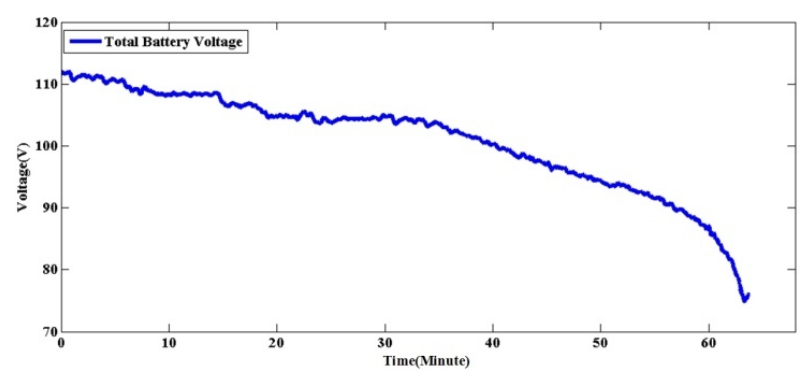

Fig. 24. Total battery voltage graph.

Electric vehicle temperature is around $32{ }^{\circ} \mathrm{C}$ as the car waits in the sun till the competition starts. At the beginning of the judge, the air flow into the vehicle dropped to $30{ }^{\circ} \mathrm{C}$. Electric vehicle temperature are given in Fig. 25.

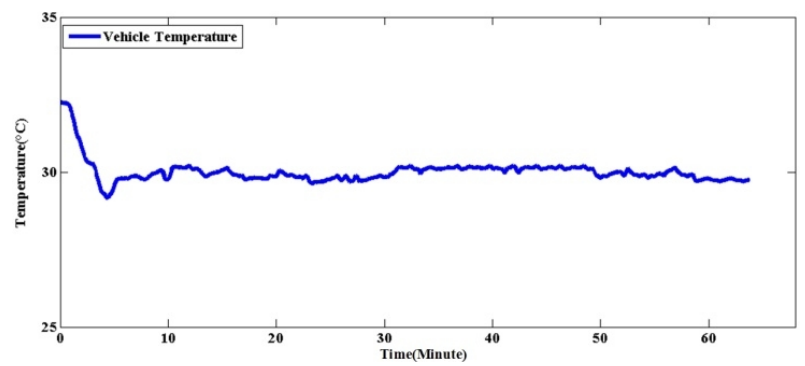

Fig. 25. Electric vehicle temperature graph.

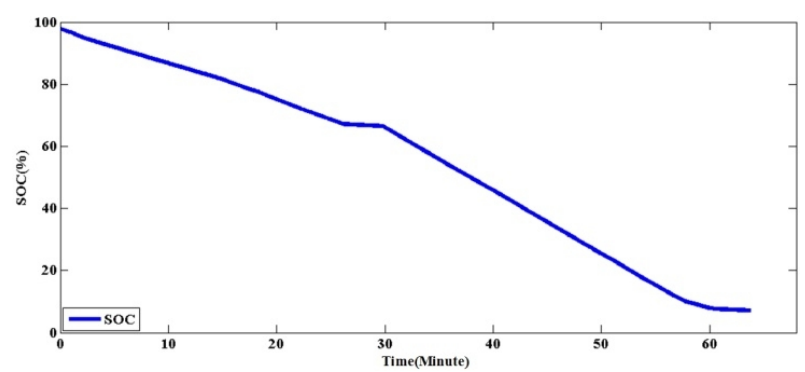

Fig. 26. Battery SOC time graph.
When the estimation chart of the SOC of the battery is analysed, the estimated SOC of the battery is $98 \%$. At the end of the contest it shows $8 \%$. The battery SOC time graph is given in Fig. 26.

\section{CONCLUSIONS}

In this study, a unique BMS is proposed to avoid problems such as overcharging, over discharge and cell balancing of battery cells. In case of system charging, discharge under constant load and tests performed by electric vehicle. During the tests, 28 battery cells in the battery were monitored for voltage and temperature. In addition, total battery voltage and battery current are monitored. The voltages of the cells in the battery pack have been adjusted to different levels. The voltages of the cells in the battery pack have been adjusted to different levels. In experimental studies, these voltage differences were compensated for. Cell-to-cell voltage differences were compensated by passive cell balancing. Up to 4 A of voltage stabilization can be performed using a $35 \mathrm{~W}$ resistor for the cell balancing circuit. Balancing current can be adjusted in balancing process. If the temperature increases, the PWM duty cycle is reduced and the balancing current drops. Fill factor is determined precisely by fuzzy logic control. The SOC of the battery was determined by the discharge curve and current counting method of the battery. Thanks to the designed battery box, it is easy to install in electric vehicle. Thanks to the fans mounted on the battery box, battery cooling can be easily performed during chargingdischarging operations. As a result of this work, a fuzzy logic controlled battery management system for electric vehicle has been realized.

\section{REFERENCES}

[1] Y. Wu, L. Zhang, "Can the development of electric vehicles reduce the emission of air pollutants and greenhouse gases in developing countries?", Transportation Research Part D: Transport and Environment, vol. 51, pp. 129-145, 2017. DOI: 10.1016/j.trd.2016.12.007.

[2] M. A. Hannan, M. M. Hoque, A. Mohamed, A. Ayob, "Review of energy storage systems for electric vehicle applications: Issues and challenges", Renewable and Sustainable Energy Reviews, vol. 69, pp. 771-789, 2017. DOI: 10.1016/j.rser.2016.11.171.

[3] Q. Wang, B. Jiang, B. Li, Y. Yan, "A critical review of thermal management models and solutions of lithium-ion batteries for the development of pure electric vehicles", Renewable and Sustainable Energy Reviews, vol. 64, pp. 106-128, 2016. DOI: 10.1016/j.rser.2016.05.033.

[4] L. H. Saw, Y. Ye, A. A. O. Tay, "Integration issues of lithium-ion battery into electric vehicles battery pack", Journal of Cleaner Production, vol. 113, pp. 1032-1045, 2016. DOI: 10.1016/j.jclepro.2015.11.011.

[5] Y. Hua, A. Cordoba-Arenas, N. Warner, G. Rizzoni, "A multi timescale state-of-charge and state-of-health estimation framework using nonlinear predictive filter for lithium-ion battery pack with passive balance control", Journal of Power Sources, vol. 280, pp. 293-312, 2015. DOI: 10.1016/j.jpowsour.2015.01.112.

[6] S. Abada, G. Marlair, A. Lecocq, M. Petit, V. Sauvant-Moynot, F. Huet, "Safety focused modeling of lithium-ion batteries: A review", Journal of Power Sources, vol. 306, pp. 178-192, 2016. DOI: 10.1016/j.jpowsour.2015.11.100.

[7] Y. Yuanmao, K. W. E. Cheng, Y. P. B. Yeung, "Zero-current switching switched-capacitor zero-voltage-gap automatic equalization system for series battery string", IEEE Trans. Power Electronics, vol. 27, no. 7, pp. 3234-3242, 2012. DOI: 10.1109/TPEL.2011.2181868.

[8] W. Li, Y. Fu, T. Liu, P. Chu, J. Wang, H. Chen, "Battery equalization based on state of charge", 2nd Int. Conf. Systems and Informatics 
(ICSAI 2014), 2014, pp. 159-163. DOI: 10.1109/ICSAI.2014.7009278.

[9] C. Hu B. D. Youn, J. Chung, "A multiscale framework with extended Kalman filter for lithium-ion battery SOC and capacity estimation", Applied Energy, vol. 92, pp. 694-704, 2012. DOI: 10.1016/j.apenergy.2011.08.002.

[10] H. Dai, X. Wei, Z. Sun, J. Wang, W. Gu, "Online cell SOC estimation of Li-ion battery packs using a dual time-scale Kalman filtering for EV applications", Applied Energy, vol. 95, pp. 227-237, 2012. DOI: 10.1016/j.apenergy.2012.02.044.

[11] E. Soylu, R. Bayir, "Measurement of electrical conditions of rechargeable batteries", Measurement and Control, vol. 49, no. 2, pp. 72-81, 2016. DOI: $10.1177 / 0020294016629178$.

[12] K. S. Ng, C. S. Moo, Y. P. Chen, Y. C. Hsieh, "Enhanced coulomb counting method for estimating state-of-charge and state-of-health of lithium-ion batteries", Applied energy, vol. 86, no. 9, pp. 1506-1511, 2009. DOI: 10.1016/j.apenergy.2008.11.021.

[13] I. N. Haq, R. H. Saputra, F. Edison, D. Kurniadi, E. Leksono, B. Yuliarto, "State of charge (SoC) estimation of LiFePO4 battery module using support vector regression", Joint Int. Conf. Electric Vehicular Technology and Industrial, Mechanical, Electrical and Chemical Engineering (ICEVT \& IMECE 2015), pp. 16-21, 2015. DOI: 10.1109/ICEVTIMECE.2015.7496640.

[14] E. Soylu, T. Soylu, R. Bayir, "Design and Implementation of SOC prediction for a Li-Ion Battery pack in an electric car with an embedded system", Entropy, vol. 19, no. 4, p. 146, 2017. DOI: 10.3390/e19040146.

[15] N. K. C. Nair, N. Garimella, "Battery energy storage systems: Assessment for small-scale renewable energy integration", Energy and Buildings, vol. 42, no. 11, pp. 2124-2130, 2010. DOI: 10.1016/j.enbuild.2010.07.002

[16] A. M. Andwari, A. Pesiridis, S. Rajoo, R. Martinez-Botas, V. Esfahanian, "A review of battery electric vehicle technology and readiness levels", Renewable and Sustainable Energy Reviews, vol. 78, pp. 414-430, 2017. DOI: 10.1016/j.rser.2017.03.138.

[17] F. Zheng, Y. Xing, J. Jiang, B. Sun, J. Kim, M. Pecht, "Influence of different open circuit voltage tests on state of charge online estimation for lithium-ion batteries", Applied energy, vol. 183, pp. 513-525, 2016. DOI: 10.1016/j.apenergy.2016.09.010.

[18] W. Waag, C. Fleischer, D. U. Sauer, "Critical review of the methods for monitoring of lithium-ion batteries in electric and hybrid vehicles", Journal of Power Sources, vol. 258, pp. 321-339, 2014. DOI: 10.1016/j.jpowsour.2014.02.064.

[19] P. E. Ross, "Boeing's battery blues [News]", iEEE Spectrum, vol. 50 no. 3, pp. 11-12, 2013. DOI: 10.1109/MSPEC.2013.6471040.

[20] B. Diouf, R. Pode, "Potential of lithium-ion batteries in renewable energy", Renewable Energy, vol. 76, pp. 375-380, 2015. DOI: 10.1016/j.renene.2014.11.058.

[21] TUBITAK Efficiency Challenge Electric Vehicle. [Online]. Available: http://challenge.tubitak.gov.tr 